\title{
Attrition Rates in a Brazilian Longitudinal Survey on Positive Psychology: Empirical and Methodological Considerations
}

\author{
Bruno Figueiredo Damásio - Universidade Federal do Rio de Janeiro, Rio de Janeiro, Brasil \\ Jonathan Bernardes Golart - Universidade Federal do Rio Grande do Sul, Rio Grande do Sul, Brasil \\ Sílvia Helena Koller - Universidade Federal do Rio Grande do Sul, Rio Grande do Sul, Brasil
}

\begin{abstract}
This study evaluates how sociodemographic and psychological variables influence the intention in participating in future waves of a positive psychology longitudinal research. Participants were 2551 Brazilian subjects (63\% female), ranging in age from 18 to 82 from 21 different States of Brazil, which responded to the first wave of the research. Several constructs of the positive psychology area were assessed. From the total, $37.7 \%$ of the participants did not accept to participate in the next waves of the study. Women were more prone to acceptting to participate when compared to men. The women who accepted presented higher levels in all "positive" psychological variables measured, and lower levels in all "negative" variables when compared to those who did not accept. For men, in turn, only pessimism influenced the intention in participating in the future waves of the study. Implications for longitudinal researches in Positive Psychology are discussed.
\end{abstract}

Keywords: Positive Psychology, longitudinal, research, gender, Brazil.

Taxas de Evasão em uma Pesquisa Longitudinal Baseada em Psicologia Positiva: Considerações Empíricas e Metodológicas

\begin{abstract}
Resumo
Este estudo avalia como variáveis sociodemográficas e psicológicas influenciam a intenção de participar em futuras etapas de uma pesquisa longitudinal focada em Psicologia Positiva. Participaram desse estudo 2551 sujeitos (63\% mulheres), com idades variando entre 18 e 82 anos, oriundos de 21 estados brasileiros, que responderam à primeira etapa do estudo. Diversos construtos psicológicos da área da Psicologia Positiva foram avaliados. Do total dos respodentes, 37,7\% não aceitaram participar das etapas futuras da pesquisa. Mulheres foram mais propensas a participar das futuras etapas em comparação aos homens. As mulheres que aceitaram apresentaram escores maiores em todas as variáveis "positivas" que foram mensuradas, além de escores menores em todas as variáveis "negativas, quando comparada com as que não aceitaram. Por outro lado, para homens apenas pessimismo influenciou na intenção de participar das etapas subsequentes do estudo. Implicações para estudos longitudinais no âmbito da Psicologia Positiva são discutidas.

Palavras-chave: Psicologia Positiva, longitudinal, pesquisa, gênero, Brasil.
\end{abstract}

Índices de Evasión en una Investigación Longitudinal Basada en Psicología Positiva: Consideraciones Empíricas y Metodológicas

\begin{abstract}
Resumen
Esto estudio evalúa como variables sociodemográficas y psicológicas influyen en la intención de participar en futuras etapas de investigación longitudinal con enfoque en la Psicología Positiva. Los participantes fueran 2551 individuos (63\% mujeres), con edades entre 18 e 82 años, oriundos de 21 estados brasileños, que respondieron a la primera etapa del estudio. Fueron evaluados diversos constructos psicológicos del área de la Psicología Positiva. De todos los encuestados 37,7\% no aceptaron participar de las futuras etapas de la investigación, existiendo más aceptación de las mujeres en comparación con los hombres. Las mujeres que aceptaron, presentaron puntuaciones mayores en todas las variables "positivas", y menores en todas las variables "negativas”, en comparación con las que no aceptaron. Por otro lado, para los hombres, sólo el pesimismo influenció en la intención de participar de las etapas subsecuentes del estudio. Son discutidas implicaciones para estudios longitudinales con enfoque en psicología positiva.

Palabras-clave: Psicología Positiva, longitudinal, investigación, género, Brasil.
\end{abstract}

Positive Psychology can be understood as the study of the conditions and processes that contribute to the flourishing or optimal functioning of people, groups and institutions (Gable \& Haidt, 2005). This political and scientific movement was officially raised in January 2000, when Seligman and Csikszentmihalyi
(2000) edited a special issue of American Psychologist claiming for the need of a larger effort in psychological researches aiming to expand the knowledge of what makes life worth living. Since this publication, the field grew tremendously, increasing considerably the number of publications of papers, books, scientific journals and 
post-graduate programs focused on the study of positive development (Gable \& Haidt, 2005; Linley, Joseph, Harrington, \& Wood, 2006).

With the balance of research aiming to comprehend psychopathology and disease as well as human strengths and well-being Psychology, as science, obtained a much larger comprehension of human functioning. Several researches have provided evidence, for example, of how positive emotions are related to physical and mental health (Schöllgen, Huxhold, Schmiedek, 2012; Worthington \& Scherer, 2004); discovered some physiological correlates of flow (Mansfield, Oddson, Turcotte, \& Couture, 2012); found out what are the long-term predictors of life-satisfaction in different cultural contexts (Daukantaitè \& Zukauskiene, 2012; Meulemann, 2001), etc. In other areas, such as education, the efforts of "positive" psychologists have provided some comprehension of how psychologists and educators can act in the basis of preventive practices within the school setting (e.g., Terjesen, Jacofsky, Froh, \& DiGiuseppe, 2004); what are and to what extent some positive psychological characteristics are related to academic achievement (e.g., Marques, PaisRibeiro, \& Lopez, 2011), etc.

Not differently from any other area, much of this acquired knowledge arose from longitudinal studies. Longitudinal studies provide one of the strongest methodologies for studying developmental changes on the cognitive, emotional and behavioral characteristics of the human being (Wolke et al., 2009). This is related to the fact that causal inferences in Psychological research present more power by means of longitudinal or experimental designs (Toh \& Hernán, 2008). Despite of its potential power, longitudinal studies can also be limited in terms of selection biases, presented in terms of follow-up losses (also termed as attrition rates or drop-out).

Attrition is a very common issue in longitudinal designs, so that it is almost impossible to conduct a longitudinal study without losing respondents throughout the process (de Leeuw, 2005). Attrition in longitudinal studies are originated from different sources, in which the most frequent are: 1) Failure from the possible respondent to locate the research unit; 2) failure from the researchers to contact the possible respondent; 3) failure in obtaining cooperation from the possible respondent to participate in the subsequent waves of the study (de Leeuw, 2005; Lepkowski \& Couper, 2002).

Attrition can also be random or systematic (Miller \& Hollist, 2007). Random attrition means that the respondents have dropped-out from different reasons that are not directly related to the study (e.g., moved to another city; had a car accident and could not participate in the study particularly in that day; passed away, etc.). Beyond reducing the number of participants (which can sometimes be very problematic, especially in studies with low $N$ ), random attrition tends to be not very severe, exactly because of its random nature. Systematic attrition, in turn, occurs when some specific groups of people drop out from the study more frequently than others (Miller \& Hollist, 2007). Thus, systematic attrition tends to be more problematic, once it is related to some specificity of the study. If the attrition rates are systematic, the results of a longitudinal study can be seriously threatened, affecting the external validity of the study (de Leeuw, 2005; Matthews et al., 2006), especially when the attrition rates are directly associated with the outcome of interest (Wolke et al., 2009). In these cases, the remaining sample is not generalizable to the original population that was initially sampled (Miller \& Hollist, 2007).

Considering that dropout can seriously impact the results and conclusion of longitudinal studies, in the current article, we aimed to evaluate the role of socio-demographic and psychological characteristics on the intention in participating in the subsequent waves of a Brazilian national survey titled "Meaning in life and subjective well-being: Interactions with optimism, hope, self-efficacy and self-esteem in different stages of the life span". As far as we know, this is the first study that explicitly aimed to evaluate the impact of positive psychological characteristics in the intention to participate in longitudinal Positive Psychology researches.

\section{Method}

\section{Participants}

Participants of this study were 2.551 Brazilian subjects ( $63 \%$ female), ranging in age from 18 to 82 $(M=30.47$ years old; $S D=11.29)$, from 21 different states of Brazil, which responded to the first wave of the project. From the total, $37.7 \%$ of the participants did not accept in participating in the next waves of the study.

\section{Instruments}

Sociodemographic Questionnaire: This instrument was used to evaluate sociodemographic characteristics of the sample (e.g., gender, age, marital status, 
financial income, educational level, religiosity/spirituality, presence or absence of chronic illness and/or special needs, etc.).

Meaning in Life Questionnaire (Damásio \& Koller, 2013" por "Damásio \& Koller, in press): The MLQ is a 10-item instrument that encompasses two different construct: Presence of meaning - MLQ-P (e.g., "My life has a clear sense of purpose") and search for meaning - MLQ-S (e.g., "I am seeking a purpose or mission for my life"). Each construct is evaluated five items. In this study, only the presence of meaning scale was employed. The scores vary from 5 to 35 . Goodness-offit indexes were: $\mathrm{CFI}=.99$; TLI $=.98$; RMSEA .079 $(.065-.094) ;$ SRMR $=.023$. Alpha reliability was .85 .

Sources of Meaning and the Meaning in Life Questionnaire (SoMe, Schnell, \& Becker, 2007; Brazilian version adapted by Damásio, Schnell, \& Koller, 2013) is a 151item questionnaire (ranging from 0 - totally disagree to 5 - totally agree) which assesses 26 different sources of meaning, as well as the levels of meaningfulness (e.g., "I lead a fulfilled life") and crisis of meaning (e.g., "I feel pain from finding no purpose in my life") by two different scales. The scores range from 0 to 5 . In this study, only the crisis of meaning subscale was used. Goodness-of-fit indexes were: CFI = .99; TLI = .99; RMSEA $(90 \%$ CI $)=.06(.05-.07)$; SRMR $=.036$.

Adult Hope Scale (AHS, Snyder et al., 1991; Brazilian version adapted by Pacico, Bastianello, Zanon, \& Hutz, in press). The AHS is a 12-item Likert-type scale (ranging from 1 - totally false to 5 - totally true) with four items assessing agency, four items assessing pathways, and four distracters items that are not considered for analysis. Agency refers to the sense of successful determination to meet goals. Pathways refer to the capacity to generate successful plans to meet goals. The scores for both agency and pathway range from 4 to 20. In the current study, the goodness-offit indexes for the expected bi-factorial solution were: CFI $=.98 ;$ TLI $=.97$; RMSEA $(90 \% \mathrm{CI})=.072(.064$ $-.080) ;$ SRMR $=.051$.

Life Orientation Test-Revised (LOT-R - Scheier, Carver, \& Bridges, 1994; Brazilian version adapted by Bastianello, Zanon, Pacico, Reppold, \& Hutz, 2012): The LOT-R evaluates one's levels of optimism (e.g., "In uncertain times, I usually expect the Best") and pessimism (e.g., "I rarely count on good things happening to me"). It is composed by ten items (4 fillers), answered in a five-point Likert scale ( $1=$ totally disagree; $5=$ totally agree). For both, pessimism and optimism scales, scores range from 4 to 20 . In this study, the expected bi-factorial solution presented excellent goodness-of-fit indexes: CFI $=.98$; TLI $=.97$; RMSEA $(90 \% \mathrm{CI})=$ $.079(.068-.091) ;$ SRMR $=.047$.

Subjective Happiness Scale (Damásio, Zanon, \& Koller, in press" por "Damásio, Zanon, \& Koller, 2014.) is a 4-item Likert-type scale (ranging from 1 to 7 points, with different anchors) which assesses subjective happiness by a single-factor solution. The scores range from 4 to 28 . The higher the scores, the higher the levels of subjective happiness. In this study, the SHS presented excellent goodness-of-fit indexes: CFI $=1.00 ;$ TLI $=.99$; RMSEA $(90 \% \mathrm{CI})=.050(.028-$ $.075) ;$ SRMR $=.012$.

Satisfaction with Life Scale (SWLS, Diener, Emmons, Larsen, \& Griffin, 1985; Brazilian version adapted by Gouveia, Milfont, Fonseca, \& Coelho, 2009) is a 5-item Likert-type scale (ranging from 1 - totally disagree to 5 - totally agree) which assess satisfaction with life by a single-factor solution. The scores range from 5 to 25. The higher the scores, the higher the levels of subjective happiness in this study, the SWLS presented excellent goodness-of-fit indexes: CFI = 1.00; TLI $=.99$; RMSEA $(90 \% \mathrm{CI})=.048(.033-.064)$; $\mathrm{SRMR}=.017$.

Rosenberg's Selfesteem Scale (RSS; Rosenberg, 1989; Brazilian version adapted by Hutz \& Zanon, 2011) is a 10-item Likert-type scale (1 - totally disagree; 4 totally agree) which assesses general self-esteem by a single-factor solution. Scores range from 10 to 40 . The higher the scores, the higher the levels of general self-esteem. In the current study, fit indexes were: CFI $=.98 ;$ TLI $=.97$; RMSEA $(90 \%$ CI $)=.079(.074$ $.085)$, SRMR $=.072$.

General Self-efficacy Scale (GSS, Schwarzer \& Jerusalém, 1995; Brazilian version adapted by Teixeira \& Dias, 2005) is a 10-item Likert-type scale (ranging from 1 - not at all true to 7 - Exactly true) which assesses general self-efficacy by a single-factor solution. The scores range from 10 to 70 . The higher the scores, the higher the levels of general self-efficacy. In the current study, fit indexes were: $\mathrm{CFI}=.98$; TLI $=.97$; RMSEA $(90 \% \mathrm{CI})=.082(.077-.088) ; \mathrm{SRMR}=.060$.

\section{Procedures}

Participants were invited to collaborate with the study through different methods. A total of $91.4 \%$ answered the questionnaires in a web-based platform, whereas the remaining $8.6 \%$ responded to the questionnaires in the paper-and-pencil form. Invitations were sent through different sources, such as personal 
and media invitations, recruitment within social and occupational institutions (specially the adults and the elderly), as well as snowball technique (Patton, 1990).

In the end of the survey, it was explained that this participation was referred to the first phase of the project and that the research would continue in the next years, with data collection intervals of one year. Initially we asked whether the participant would be interested to continue in the next waves of the study, and then we asked for any kind of information that could help us to locate him/her (e.g., home address; telephone number; e-mail address, etc). It was explained that these personal informations would be obtained only for future contacts, and that the responses to the questionnaire would be totally anonymous. Participants interested in participating the next waves of the project answered positively to the interest question, and left information for that the research team could contact him/her. Those who refused in participating answered negatively to the interest question and provided no personal information, making explicit their non-interest in continuing in the study. The participants who did not agree in participating in the next waves of the study were coded as 0 , and those who agreed in participating were coded as 1 .

\section{Data Analysis}

We aimed to evaluate the role of sociodemographic variables and psychological characteristics in the intent or not in participating in a second-wave of this study. Sociodemographic variables evaluated were: age, gender, partnership (yes/no); children (presence/ absence); religiosity/spirituality (yes/no); educational level; job (yes/no); job satisfaction (yes/no); financial dependency (yes/no); monthly income; chronic disease (presence/absence). For the categorical variables (gender, religiosity, partnership, children, job, job satisfaction, financial dependency, chronic disease) chi-square $\left(\chi^{2}\right)$ tests were conducted. For the ordinal variables (age, educational level, monthly income), a MANOVA was conducted. Age was coded as years old. Educational level was categorically ordered (1 incomplete elementary school; 2 - complete elementary school; 3 - incomplete high school; 4 - complete high school; 5 - incomplete college education; 6- complete college education; 7 - incomplete graduate school; 8 - complete graduate school); monthly income was ordered according to minimum wages $(1-$ less or equal 1 minimum wage; 2 - between one to three minimum wages; 3 - between three to five minimum wages; 4
- from five to eight minimum wages; 5 - more than eight minimum wages).

Psychological characteristics evaluated included: meaning in life (presence); crisis of meaning; hope; optimism, pessimism; subjective happiness, life satisfaction, self-esteem and self-efficacy. Two multivariate analysis of co-variance (MANCOVA; one for male and another for female) using all psychological characteristics (above mentioned) as dependent variables, participation (yes/no) as factor, and chronic disease as covariate were conducted.

The MANCOVA implemented bootstrapping (1000 re-samplings) procedures, with a $99 \%$ confidence interval for the mean difference $(\Delta M)$. Bootstrapping was used to achieve a greater reliability of the results, to correct the non-normal distribution of the sample and the difference in group sizes and to present a confidence interval of $99 \%$ for the mean differences (Haukoos \& Lewis, 2005).

\section{Results}

Initially we sought to examine the relations among gender, religiosity, partnership, children, job, job satisfaction, financial dependency, and chronic disease in the intent to participate in the study. The $c^{2}$ test provided evidences of a gender effect in the intent to participate in the subsequent phases of the study. An odds-ratio (OR) evaluation showed that women were found 1.74 times more prone to continue in the study when compared to men. Chronic disease presented marginal significant effects in the intent to participate (See Table 1).

The omnibus MANOVA using age, educational level and monthly income as DV and the intent in participating in the study as factor presented significant effects (Wilk's Lambda $=.99, F[2.547,3]=6.54, p<$ .000). Specific effects, however, were found only for monthly income. Participants who intended to participate in the next waves of the study were predominantly poorer. Despite the significant association, the effect size was very low (See Table 2).

In order to evaluate the effects of the psychological variables in the intent to participate in the subsequent phases of the study, two MANCOVAS were conducted, one for male and the other for female participants. The MANCOVAS included all psychological variables as DV, chronic disease and monthly income as covariates, and intent in participating in the subsequent phases of the study as factor. 
Table 1

Chi-Square Associations among Sociodemographic Variables and Intent to Continue in Subsequent Waves of the Study

\begin{tabular}{|c|c|c|c|c|c|}
\hline \multirow{2}{*}{$\begin{array}{l}\text { Variables } \\
\text { Yes }\end{array}$} & & \multicolumn{2}{|c|}{ Intent in Participating } & \multirow{2}{*}{$\chi^{2}$} & \multirow{2}{*}{$p$-value } \\
\hline & & No & & & \\
\hline \multirow{2}{*}{ Gender } & Female & 1037 & 570 & 9.28 & \multirow{2}{*}{.001} \\
\hline & Male & 552 & 392 & & \\
\hline \multirow{2}{*}{ Religiosity/spirituality } & Yes & 1.168 & 678 & 2.746 & \multirow{2}{*}{.11} \\
\hline & No & 420 & 284 & & \\
\hline \multirow{2}{*}{ Partnership } & Yes & 485 & 281 & .491 & \multirow{2}{*}{.50} \\
\hline & No & 1104 & 681 & & \\
\hline \multirow{2}{*}{ Children } & Yes & 414 & 222 & 2.838 & \multirow{2}{*}{.10} \\
\hline & No & 1175 & 740 & & \\
\hline \multirow{3}{*}{ Job } & Yes & 1060 & 625 & 1.074 & \multirow{3}{*}{.58} \\
\hline & No & 498 & 320 & & \\
\hline & Retired & 31 & 17 & & \\
\hline \multirow{2}{*}{ Job satisfaction } & Yes & 833 & 507 & 1.266 & \multirow{2}{*}{.26} \\
\hline & No & 229 & 121 & & \\
\hline \multirow{2}{*}{ Financial dependency } & Yes & 761 & 489 & 2.072 & \multirow{2}{*}{.16} \\
\hline & No & 828 & 473 & & \\
\hline \multirow{2}{*}{ Chronic disease } & Yes & 266 & 133 & 3.858 & \multirow{2}{*}{.06} \\
\hline & $\mathrm{No}$ & 1323 & 829 & & \\
\hline
\end{tabular}

Note. $\chi^{2}-$ chi-square; $p$-value - exact

As can be seen in Tables 3 and 4, the results were largely different for women when compared to men. Women who accepted in participating in the subsequent phases of the study presented higher indexes in all positive psychological variables, and lower levels in both pessimism and crisis of meaning (the only two "negative" measures) (See Table 3). For men, in turn, the unique measure that presented significant effect on the intent to participate in the subsequent phases of the study was pessimism. Those who accepted in participating presented lower levels of pessimism when compared to those who did not accepted.

\section{Discussion}

Our results showed an intriguing different pattern of psychological functioning of men and women on the intention of participating in the subsequent waves of a longitudinal Positive Psychology research. Initially, it was shown that women were almost two times more prone to participate in the next waves of the study. However, subsequent results showed that, for continuing their participation, women depended on their levels of well-being (in this study, measured by 10 different indicators), whereas men did not.

These findings are not easily to comprehend. However, it seems to be related to gender-related motivational and emotional aspects. Thus, we hypothesize several possibilities of explanation, in order to clarify the obtained results.

Gender-related literature shows that human differentiation on the basis of gender is a fundamental phenomenon that affects virtually every aspect of people's daily lives (Bussey \& Bandura, 1999). Studies based on personality traits, have shown, for example, that women presents higher levels of neuroticism (in other words, emotional instability) when compared to men (Hutz \& Nunes, 2001; Oliveira, 2002; Zanon, Borsa, Bandeira, \& Hutz, 2012), and this pattern is consistent across several different nations (Costa Jr., Terracciano, \& McCrae, 2001; Lynn \& Martin, 1997). Further, it is also known that personality traits, especially neuroticism, in interaction with gender, tends to impact the on self-efficacy and on performance in different areas of people's lives (Schmitt, 2007). Thus, we argue that men are less likely to initiate and 
Table 2

MANOVA Effects among Sociodemographic Variables and Intent to Continue in Subsequent Waves of the Study

\begin{tabular}{|c|c|c|c|c|c|}
\hline \multirow{3}{*}{ Variables } & \multicolumn{2}{|c|}{ Intent in participating } & \multirow{3}{*}{$F$} & \multirow{3}{*}{$n^{2}$} & \multirow{3}{*}{$p$-value } \\
\hline & Yes & No & & & \\
\hline & Mean (SD) & Mean (SD) & & & \\
\hline Age & $30.81(11.39)$ & $29.93(11.07)$ & 3.61 & .001 & .06 \\
\hline Educational level & $6.24(1.37)$ & $6.24(1.38)$ & 0.00 & .000 & .99 \\
\hline Monthly income & $3.44(1.27)$ & $3.62(1.27)$ & 12.04 & .005 & .001 \\
\hline
\end{tabular}

Note. $n^{2}$ - eta-squared (effect size measure)

Table 3

MANCOVA Effects among Psychological Variables and Intent to Continue in Subsequent Waves of the Study for Women

\begin{tabular}{|c|c|c|c|c|c|}
\hline \multirow{3}{*}{ Variables } & \multicolumn{2}{|c|}{ Intent in participating } & \multirow{3}{*}{$F$} & \multirow{3}{*}{$p$-value } & \multirow{3}{*}{$n^{2}$} \\
\hline & Yes & No & & & \\
\hline & Mean (SD) & Mean (SD) & & & \\
\hline Pessimism & $11.67(2.19)$ & $11.02(2.35)$ & 30.522 & .000 & .02 \\
\hline Optimism & $6.50(2.47)$ & $6.96(2.55)$ & 15.704 & .000 & .01 \\
\hline Hope (agency) & $15.43(2.44)$ & $15.09(2.28)$ & 9.889 & .002 & .01 \\
\hline Hope (pathway) & $15.89(2.22)$ & $15.47(2.39)$ & 13.529 & .000 & .01 \\
\hline Presence of meaning & $25.62(6.31)$ & $24.54(6.30)$ & 12.837 & .000 & .01 \\
\hline Crisis of meaning & $5.08(5.59)$ & $5.80(5.72)$ & 9.637 & .000 & .01 \\
\hline Life satisfaction & $25.09(6.08)$ & $24.60(6.01)$ & 5.823 & .000 & .01 \\
\hline Subjective happiness & $20.76(4.82)$ & $19.66(5.09)$ & 21.823 & .000 & .01 \\
\hline Self-esteem & $32.66(4.97)$ & $31.53(5.07)$ & 25.730 & .000 & .02 \\
\hline Self-efficacy & $31.04(4.70)$ & $30.02(4.86)$ & 19.130 & .000 & .01 \\
\hline
\end{tabular}

Table 4

MANCOVA Effects among Psychological Variables and Intent to Continue in Subsequent Waves of the Study for Men

\begin{tabular}{|c|c|c|c|c|c|}
\hline \multirow{3}{*}{ Variables } & \multicolumn{2}{|c|}{ Participation } & \multirow{3}{*}{$F$} & \multirow{3}{*}{$p$-value } & \multirow{3}{*}{$n^{2}$} \\
\hline & Yes & No & & & \\
\hline & Mean $(S D)$ & Mean $(S D)$ & & & \\
\hline Pessimism & $6.83(2.66)$ & $7.25(2.60)$ & 6.21 & .013 & .01 \\
\hline Optimism & $11.35(2.41)$ & $11.29(2.24)$ & .32 & .57 & .00 \\
\hline Hope (Agency) & $15.21(2.47)$ & $15.28(2.44)$ & .14 & .71 & .00 \\
\hline Hope (Pathway) & $16.05(2.35)$ & $16.01(2.12)$ & .03 & .85 & .00 \\
\hline Presence of meaning & $24.14(6.73)$ & $23.69(6.54)$ & 1.19 & .28 & .00 \\
\hline Crisis of meaning & $5.83(6.00)$ & $6.18(6.10)$ & .97 & .32 & .00 \\
\hline Life satisfaction & $24.22(6.07)$ & $24.54(5.84)$ & .35 & .55 & .00 \\
\hline Subjective happiness & $19.62(5.14)$ & $19.79(4.87)$ & .10 & .75 & .00 \\
\hline Self-esteem & $32.20(5.13)$ & $31.94(4.99)$ & .76 & .38 & .00 \\
\hline Self-efficacy & $31.29(4.75)$ & $31.18(4.50)$ & .22 & .64 & .00 \\
\hline
\end{tabular}


to continue in the subsequent phases of the study, however, those who decide to participate and also to continue do not depend on their level of positivevariables (except pessimism). Rather, it seems that the motivational aspects that make men decide participate on the research are outside themselves, like a self-transcendence interest in collaborating with the research. If this perspective is correct, it might explain why only the levels of pessimism are related with men's decision in participating or not in the subsequent waves. Pessimism is comprehended as a self-regulative and relative stable belief that negative outcomes will occur instead of positive outcomes (Carver \& Scheier, 2001). Pessimist people tend to be resistant to act toward any object or situation if they belief the outcome related to their action will not result positively (Carver, Scheier, \& Sergestrom, 2010). That is, if people belief that one event will result in a negative manner, there will be greater resistance to initiate a behavior directed to this event and for maintaining an active engagement (Carver \& Scheier, 2001). We hypothesize that pessimist men decide not to participate in the following waves of the study because they do not believe in the possible benefits of the scientific research they were invited to collaborate.

Regarding the results presented to the women, it is possible to argue that women decision of continuing or not in the subsequent waves of the study are more related to their self cognitive and emotional characteristics. Once women tend to be more emotionally instable than men (Costa Jr. et al., 2001), it is possible that the response on a battery of questionnaires that directly leads to emotional aspects (e.g., "I general, I consider myself: Not a very happy person or a very happy person") destabilizes more women than men. Thus, it is possible that women with lower levels of positive characteristics do not want to face this reality again, so that they decided not to continue their participation.

Albeit the causal mechanisms related to these findings are not totally understood, one thing is clear: The subsequent phases of this study will count only with women presenting higher levels of positive characteristics, and this sample will not be generalizable to the original sample, once our attrition for women are highly associated with the main variables of the study (Wolke et al., 2009).

It is important to note that this study is not free of limitations. First, our sample is not representative of the Brazilian population, so generalization of these findings is not appropriate. Second, our results refer to the intention of participating. Nothing guarantees that those who told that they would like to participate in the next waves of the study will do so. So, future comparison among these different groups (those who said that would not like to participate; said that would like to participate but did not; and said that would like to participate and did) would help us to better comprehend how the psychological measured variables influence their decision and action toward the research. Third, the original aim of this research project was not to investigate longitudinal attrition rates. The independent variables of the employed model are solely related to those variables in which authors had theoretical interests. So, it is possible that other important variables related to the outcome (intention of participating) had been neglected.

\section{Conclusions}

As far as we know, this is the first study that explicitly aimed to evaluate the impact of positive psychological characteristics in the intention to participate in longitudinal Positive Psychology researches. It is not known the extent to which these differences would appear for other areas of study, or even a similar study in a different culture. However, we believe that these results highlight concerns related to participants' loses in longitudinal Positive Psychology studies. Specifically, we provided evidence of a very different pattern of interaction of gender and psychological characteristics, which impacted people's intention of participating in the next waves of this study.

The consequences of deriving our findings of a longitudinal study in a biased women sample can strongly impact our conclusions and threaten possible interventions plans. This is because the thought evidenced-based intervention would not accomplish data from the women who would really benefit from it (those with lower scores on the positive variables and higher scores in the negative variables).

Future studies are necessary to better clarify the mechanisms presented here. With the development of this knowledge, researches would be able to better plan adequate methods of reducing their attrition rates.

\section{References}

Bastianello, M. R., Zanon, C., Pacico, J. C., Reppold, C., \& Hutz, C. S. (2012). Optimism, self-esteem, and personality: Adaptation and validation of the 
Revised Life Orientation Test LOT-R. Manuscript submitted for publication.

Bussey, K., \& Bandura, A. (1999). Social cognitive theory of gender development and differentiation. Psychological Review, 106(4), 676-713. doi:10.1037/0033-295X.106.4.676

Carver, C. S., \& Scheier, M. F. (2001). Optimism, pessimism, and self-regulation. In E. C. Chang (Ed.), Optimism and pessimism: Implications for theory, research, and practice (pp. 31-51). American Psychological Association: Washington, DC.

Carver, C. S., Scheier, M. F., \& Segerstrom, S. C. (2010). Optimism. Clinical Psychology Review, 30(7), 879-889. doi:10.1016/j.cpr.2010.01.006

Costa Jr, P., Terracciano, A., \& McCrae, R. R. (2001). Gender differences in personality traits across cultures: Robust and surprising findings. Journal of Personality and Social Psychology, 81(2), 322-331. doi:10.1037/0022-3514.81.2.322

Damásio, B, F., \& Koller, S. H. (in press). Meaning in life questionnaire: Adaptation process and psychometric properties of the Brazilian version. Revista Latinoamericana de Psicologia.

Damásio, B. F., Schnell, T., \& Koller, S. H. (2013). Sources of meaning and meaning in life questionnaire (SoMe) in the Brazilian context: Adaptation, psychometric properties and sociodemographic findings in a large Brazilian sample. Acta de Investigación Psicológica, 3(3), 1205-1227.

Damásio, B. F., Zanon, C., \& Koller, S. H. (2014). Validation and psychometric properties of the Brazilian version of the subjective happiness scale. Universitas Psychologica, 13(1), 1-13. doi: 10.11144/ Javeriana.UPSY13-1.vppb

Daukantaite, D., \& Zukauskiene, R. (2012). Optimism and subjective well-being: Affectivity plays a secondary role in the relationship between optimism and global life satisfaction in the middle-aged women: Longitudinal and cross-cultural findings. Journal of Happiness Studies, 13(1), 1-16. DOI 10.1007/s10902-010-9246-2

de Leeuw, E. D. (2005). Dropout in longitudinal studies: Strategies to limit the problem. In B. S. Everitt, \& D. C. Howell (Eds.), Encyclopedia of Statistics in Behavioral Science (pp. 515-518). Chichester: Wiley.
Diener, E., Emmons, R. A., Larsen, R. J., \& Griffin, S. (1985). The Satisfaction with life scale. Journal of Personality Assessment, 49(1), 71-75. doi: 10.1207/ s15327752jpa4901_13

Gable, S. L., \& Haidt, J. (2005). What (and Why) is Positive Psychology? Review of General Psychology, 9(2), 103-110. doi:10.1037/1089-2680.9.2.103

Gouveia, V. V., Milfont, T., Fonseca, P. N., \& Coelho, J. A., P. M. (2009). Life satisfaction in Brazil: Testing the psychometric properties of the satisfaction with life scale (SWLS) in five Brazilian samples. Social Indicators Research, 90(2), 267-277. doi:10.1007/ s11205-008-9257-0

Haukoos, J. S., \& Lewis, R. J. (2005). Advanced statistics: Bootstrapping confidence intervals for statistics with "difficult" distributions. Academic Emergency Medicine, 12(4), 360-365. doi:10.1197/j. aem.2004.11.018

Hutz, C. S., \& Nunes, C. H. S. S. (2001). Escala fatorial de ajustamento emocional/neuroticismo. São Paulo: Casa do Psicólogo.

Hutz, C. S., \& Zanon, C. (2011). Revisão da adaptação, validação e normatização da escala de autoestima de Rosenberg. Avaliação Psicológica, 10(1), 41-49.

Lepkowski, J. M., \& Couper, M. P. (2002). Nonresponse in the second wave of longitudinal household surveys. In R. M. Groves, D. A. Dillman, J. L., Eltinge, \& R. J. A. Little (Eds.), Survey Nonresponse. New York: Wiley.

Linley, P. A., Joseph, S., Harrington, S., \& Wood, A. M. (2006). Positive psychology: Past, present, and (possible) future. The Journal of Positive Psychology, 1(1), 3-16. doi:10.1080/17439760500372796

Lynn, R., \& Martin, T. (1997). Gender differences in extraversion, neuroticism, and psychoticism in 37 nations. The Journal of Social Psychology, 137(3), 369373. doi:10.1080/00224549709595447

Lyubomirsky, S., \& Lepper, H. S. (1999). A measure of subjective happiness: Preliminary reliability and construct validation. Social Indicators Research, 46(1), 137-155. doi:10.1023/A:1006824100041

Mansfield, B. E., Oddson, B. E., Turcotte, J., \& Couture, R. T. (2012). A possible physiological correlate for mental flow. The Journal of Positive Psychology, 7(4), 327-333. doi:10.1080/17439760.2012.691982 
Mathews, F. E., Chatfield, M., Brayne, C., \& Medical research council and ageing study (2006). An investigation of whether factors associated with short-term attrition change or persist over ten years: Data from the medical research council cognitive function and ageing study (MRC CFAS). BMC Public Health 6(6), 185-195. doi:10.1186/1471-2458-6-185

Marques, S., Pais-Ribeiro, J., \& Lopez, S. (2011). The role of positive psychology constructs in predicting mental health and academic achievement in children and adolescents: A two-year longitudinal study. Journal of Happiness Studies, 12(6), 1049-1062. doi:10.1007/s10902-010-9244-4

Meulemann, H. (2001). Life satisfaction from late adolescence to mid-life: The impact of life success and success evaluation on the life satisfaction of former gymnasium students between ages 30 and 43 . Journal of Happiness Studies, 2(4), 445-465.

Miller, R. B., \& Hollist, C. D. (2007). Attrition bias. In N. Salking (Ed.), Encyclopedia of Measurement and Statistics (3rd vol.) (pp. 57-60). Thousand Oaks: Sage Reference.

Oliveira, J. H. B. (2002). Neuroticismo: Algumas variáveis. Análise Psicológica, 4(20), 647-655. Retrieved from http://www.scielo.gpeari.mctes.pt/ pdf/aps/v20n4/v20n4a09.pdf

Pacico, J. C., Bastianello, M. R., Zanon, C., \& Hutz, C. S. (in press). Adaptation and validation of the dispositional hope scale for adolescents. Psicologia: Reflexão e Crítica.

Patton, M. Q. (1990). Qualitative evaluation and research methods (2nd ed.). Newbury Park: Sage.

Rosenberg, M. (1989). Society and the adolescent self-image. Revised Edition. Middletown, CT: Wesleyan University Press.

Scheier, M. F., Carver, C. S., \& Bridges, M. W. (1994). Distinguishing optimism from neuroticism (and trait anxiety, self-mastery, and self-esteem) - a reevaluation of the Life Orientation Test. Journal of Personality and Social Psychology, 67(6), 1063-1078. doi:10.1037/0022-3514.67.6.1063

Schmitt, N. (2007). The interaction of neuroticism and gender and its impact on self-efficacy and performance. Human Performance, 21(1), 49-61. doi:10.1080/08959280701522197
Schöllgen, I., Huxhold, O., \& Schmiedek, F. (2012). Emotions and physical health in the second half of life: Interindividual differences in age-related trajectories and dynamic associations according to socioeconomic status. Psychology and Aging, 27(2), 338-352. doi: 10.1037/a0026115

Schwarzer, R., \& Jerusalem, M. (1995). Generalized Self-Efficacy scale. In J. Weinman, S. Wright \& M. Johnston (Eds.), Measures in health psychology: A user's portfolio. Causal and control beliefs (pp. 35-37). Windsor, UK: NFER-NELSON.

Seligman, M. E. P., \& Csikszentmihalyi, M. (2000). Positive psychology: An introduction. American Psychologist, 55(1), 5-14. doi:10.1037/0003-066X.55.1.5

Snyder, C. R., Harris, C., Anderson, J. R., Holleran, S. A., Irving, L. M., Sigmon, S. T., ..., \& Harney, P. (1991). The will and the ways: Development and validation of an individual differences measure of hope. Journal of Personality and Social Psychology, 60(4), 570-585. doi:10.1037/0022-3514.60.4.570

Steger, M. F., Frazier, P., Oishi, S., \& Kaler, M. (2006). The meaning in life questionnaire: Assessing the presence of and search for meaning in life. Journal of Counseling Psychology, 53(1), 80-93. doi:10.1037/0022-0167.53.1.80

Teixeira, M. A. P., \& Dias, A. C. G. (2005). Propriedades psicométricas da versão traduzida para o português da escala de autoeficácia geral percebida de Ralph Schwarzer. In Instituto Brasileiro de Avaliação Psicológica (Ed.), Abstracts of the Second Brazilian Congress of Psychological Assessment. Gramado: IBAP.

Terjesen, M. D., Jacofsky, M., Froh, J., \& DiGiuseppe, R. (2004). Integrating positive psychology into schools: Implications for practice. Psychology in the Schools, 41(1), 163-172.

Toh, S., \& Hernán, M. A. (2008). Causal inference from longitudinal studies with baseline randomization. International Journal of Biostatistics, 4(1), 1-30

Wolke, D., Waylen, A., Samara, M., Steer, C., Goodman, R., Ford, T., \& Lambers, K. (2009). Selective drop-out in longitudinal studies and non-biased prediction of behaviour disorders. The British Journal of Psychiatry, 195(1), 249-256. doi: 10.1192/bjp. bp.108.053751

Worthington, E. L., \& Scherer, M. (2004). Forgiveness is an emotion-focused coping strategy that can reduce 
health risks and promote health resilience: Theory, review, and hypotheses. Psychology \& Health, 19(3), 385-405. doi:10.1080/0887044042000196674

Zanon, C., Borsa, J. C., Bandeira, D. R., \& Hutz, C. S. (2012). Relações entre pensamento ruminativo e facetas do neuroticismo. Estudos de Psicologia (Campinas), 29(2), 173-181. doi:10.1590/ S0103-166X2012000200003

Recebido: $17 / 06 / 2014$

$1^{a}$ reformulação: 01/08/2014

Aprovado: 07/11/2014

Sobre os autores:

Bruno Figueiredo Damásio é professor adjunto A do Instituto de Psicologia/Departamento de Psicometria da Universidade Federal do Rio de Janeiro e desenvolve pesquisas com temáticas relacionadas à Psicologia Positiva, com ênfase em Psicometria, especialmente, técnicas de modelagem de equações estruturais e Teoria de Resposta ao Item.

Jonathan Bernardes Golart é graduando em Psicologia pela Universidade Federal do Rio Grande do Sul (UFRGS).

Sílvia Helena Koller é professora da Universidade Federal do Rio Grande do Sul, pesquisadora 1A do CNPQ, orientadora de doutorado e mestrado e coordenadora do Centro de Estudos Psicológicos (CEP-Rua).

Contato com os autores:

Universidade Federal do Rio de Janeiro (UFRJ)

Instituto de Psicologia, Departamento de Psicometria

Avenida Pasteur, 250, Urca, Rio de Janeiro - RJ, Brasil

CEP: 22290-902.

E-mail:bf.damasio@gmail.com 